\title{
The Portrayal of Gender Inequality in Selected Female Oriented Bollywood Movies
}

Priyanka Marwaha

Research Scholar

English

CT University

Ludhiana, Punjab, India

marwahapriyanka@gmail.com

\section{Abstract}

Men have been considered superior in most cultures since they have been the ones who bring home the bacon, whereas women have always been considered a subject to her father, husband or son, thus inferior. Cinema is not just a modern-day art; rather it is a modern-day mind; while watching a film, we are constantly watching ourselves. In the form of a mirror, Cinema has sharply reflected the Indian psyche and the changing roles of women from time to time. This paper deals with gender inequality and its influence on the patriarchal Indian society with a focus on some female-oriented Bollywood movies. It also tries to highlight how, even though the Indian Constitution emphasises gender equality, Indian Cinema has failed to provide decision making roles to women in Bollywood movies.

Keywords: Gender Inequality, Indian Cinema, Bollywood, Female Oriented Movies, Female Roles. 


\section{Introduction}

Over the years, the concept of gender roles has taken new dimensions, and this has primarily affected the portrayal of gender issues, especially gender contrarieties in Cinema. Based on the sociological aspect, 'gender' refers to defining male and female by the society that differentiates and assigns different roles to them based on their physical ability or sexuality. The process of gender discrimination begins as soon as a child is born into a family. On the one hand, where the birth of a son is celebrated on Lohri, and both mother and child are showered with love and blessings, the birth of a daughter is considered to be filled with pain and burden.

According to the Oxford Reference Dictionary, Gender inequality refers to a 'social process by which people are treated differently and disadvantageously, under similar circumstances, based on gender'. Right from childhood, gender differentiation is evident in the behaviour of parents and people around, based on the sex of the children. For instance, girls generally get toys like dolls and kitchen sets, etc. that induce communion, nurturing, and intimacy; whereas boys get toys like cars, guns, etc. that induce independence and competitiveness in them. Education, though, is helping in bridging the gap created due to gender inequality but, equal employment opportunities and salary to both still is a distant dream.

\section{Cinema and Society}

Cinema is considered a significant point of reference for Indian culture and society. It has conveyed the changing scenarios and form of India's cultural and societal sentiments incredibly to the extent that no former art form could ever achieve. Cinema is not just a modern day art; rather it is a modern-day mind; while watching a film, we are constantly watching ourselves. In the form of a mirror, it has sharply reflected the Indian psyche from 
time to time. Not only does it just reflect, but it has also shaped and influenced society over time. It is believed that Cinema and society influence each other, if not, then where do the films get their inspiration from?

The world or society that we live in is constantly changing, and the same changes are produced in the Cinema. For instance, the depiction of 'Maa' in the Hindi movies of the ' $60 \mathrm{~s}$, '70s right till the '80s was that she cared about nothing but her children and the one who used to burn the midnight oil doing menial jobs to afford two meals a day or to pay for the hero's education, which has now been replaced by the modern, educated and sometimes even independent 'Mom', but no matter which era it is, she is an epitome of sacrifice and hard work.

Cinema helps in reflecting on the changes that take place in society as well as it paints the picture of politics and the economy of present times. From the emergence of small towns to the growth of the middle class; from the depiction of enslavement, hopelessness, anger, isolation, and separation to liberation, optimism, pleasure, accessibility, and togetherness. Observers and analysts believe that movies have been playing a crucial role as a mass medium since its inception. Despite the tremendous growth in the making and examining of the movies over the years, a thorough study of films has remained entirely underdeveloped. Though an ocean of material has been produced, just a handful of it has provided meaningful perception about the nature of the movies and their role in the society.

\section{The Portrayal of Women in Bollywood}

When one thinks of India, it's hard not to think about Bollywood. Over nine decade-long history, Bollywood has seen the females take on different forms, be it a sacrificing mother, a damsel in distress or a woman in charge of her destiny. But the one thing that becomes clear while looking at the chart of the evolution of the role of women in Bollywood is largely the role of the viewers' gaze. 
English art critic and novelist John Berger, in his 1972 essay on Art Criticism (pp-47), Ways of Seeing, said, "Men act, women appear. Men watch, women watch themselves being watched." The quote helps to interpret the portrayal of women in media, but more importantly, it tries to put forth the effect of the 'male gaze' on the art form being viewed, which in this case is Cinema. Due to the contrariety in the number of men compared to women in the writing process, female characters in Bollywood are being presented through the lens of the male perspective. Gender bias has travelled across decades, and still, we haven't got ourselves rid of the obsolete notions that existed almost a century ago.

For every movie like 'Nil Battey Sannata', 'Queen', or 'Lipstick Under My Burkha', we have movies like 'Grand Masti', 'Mastizaade' or 'Golmaal', where the female lead is either a reason why the hero goes through a character transformation, or she is objectified to provide visual relief from the action. This objectification of women is also evident from the fact that most of the mainstream Bollywood movies have an "Item Number" just to ensure that it attracts a good amount of male gaze.

The change has been slow, but the female filmmakers like Deepa Mehta, Meghna Gulzaar, Gauri Shinde, Alankrita Shrivastava, etc., are taking charge of the narrative, and actors themselves-Priyanka Chopra, Anushka Sharma, Deepika Padukone, Sonam Kapoor-are venturing into production ensuring that Bollywood produces movies where the woman are playing decision making roles.

Indian Cinema began its journey with mythological stories and great epics like Raja Harishchandra, directed by Dadasaheb Phalke in 1913, the country's first-ever feature film. Initially, women were not allowed to be a part of films; thus, male artists used to play female roles as well. Ardeshir Irani through 'Alam Ara' changed the face of Indian Cinema by redefining the importance of women, (starring Zubeida Begum as the female lead) and introducing sound in films in 1931. 
The 1930s to late 1940s, Indian Cinema showcased anger and demand for independence from British Colonisers. Post-independence, Indian Cinema produced movies based on social issues and everyday problems and portrayed a society that people desired to achieve.

The 1950s to late 1970s is considered the 'Golden Era' of Bollywood since it portrayed the more idealistic picture of society. The country was enjoying its newfound freedom, and the atmosphere of new aspirations and new beginnings demonstrated itself in Hindi cinema as well. Films produced during these years focused on the themes like India's rich culture, rural-urban development, overcoming gender or class inequalities, the significance of relationships, importance of customs, norms and ethics. The women got equally important and dominant roles in the films along with the male actors. Thus both shared the responsibility on their shoulders to sell the movie in the market.

One of the notable movies of this era was 'Mother India'- the idea was to celebrate women as the nation's pillar of strength - a thought that is perfectly represented in the iconic movie poster that shows Nargis with a wooden plough. Directed by Mehboob in 1957, it combined socialistic ideals with traditional values. In the opening scene of the film, Radha (Nargis Dutt) a woman in her late years referred to as the 'Mother' of the village, is asked to inaugurate a new canal constructed in her village by the men presiding over the function. The term Bharat Mata, i.e., (Mother India) is a part of the Indian consciousness. Radha is shown as a common woman, an ideal wife, an obedient daughter-in-law and a caring mother. Women watching this film can easily identify with her, and the men will recognise her as their sister, wife or mother.

Though female characters were an essential part of the narrative; they were often portrayed through a patriarchal lens. For instance, Waheeda Rahman's role in the 1965 classic 'The Guide'. Rosie leaves her disloyal and unsupportive husband to follow her passion for being a successful dancer and for being with a man she loves. However, she leaves Raju too when he 
did not turn out to be what she thought he was. Thus to some extent, female actors of that era enjoyed the decision making roles.

The 1970s- 1980s burst the idealistic bubble of the '60s, giving way to the more realistic picture of how the audiences identified women in their real life depicted onscreen. It was the period when women in Bollywood got the role either of a mother or a dutiful wife. The leading ladies had to undergo taunts and oppression in respectful silence. The uncertainty of those times was highlighted through the way women were portrayed onscreen, celebrating her as a more traditional mother figure. Two movies that perfectly depict this theory are 'Jai Santoshi Maa' (1975), and 'Seeta Aur Geeta' (1972). Both the movies presented, the 'good' female character as an oppressed and fearful woman who suffered the mental and physical torture from her family members quietly. This depiction of bearing the pain in silence shown as a virtue that all women must-have. Of course towards the end, they eventually get their happy ending, but they remained subservient as they were in the beginning, with a happy ending for the audience that comprised mostly men.

The 1980s-90s witnessed the rise of the action star; it was the time when Bollywood heroines lost their screen timings and space to the heroes. The female lead was reduced to a magnetic component of the films who used to dance around trees or were kidnapped, raped and killed. A larger-than-life hero was given a reason, the (attempted) rape or murder of his sister, girlfriend or any other woman in his life, to deliver a crowd-pleasing dialogue and beat up the bad guys in a choreographed fight sequence. Thus the role of the female lead was reduced to a one-dimensional character, her entire existence in the narrative of the story was first to be at the mercy of the bad guy, and when that does not work, then call for her brother/boyfriend/husband, who will fight bravely and eventually save her or take her revenge. The female leads in the 90s had wholly lost the space they had created for themselves. As films became universal and hi-tech, the heroes took centre stage whereas the heroines were more of 
a glamour component. The more global Bollywood became, the more regressed were the films. Most of the hits films of the 1990s showed a desire for a traditional way of life where the women kept their homes and men earned the bread. Madhuri Dixit through 'Hum Apke Hai Kaun' and Kajol through 'Dilwale Dulhaniya Le Jayenge' stole millions of hearts, but they also established the trend that heroines ought not to put their dreams ahead of the aspirations and desires of the family.

The early 2000s Bollywood rejected the ideas previously held close by the society. This was mainly due to the shift in the audience's awareness of gender inequality in the storytelling of these movies. With the increased participation of women in the writing process, female perspective and opinions were presented in brand new dimensions. With the rapid growth of the internet and with the increasing literacy rate, the audience grew and appreciated the progressive Cinema from around the world and started rejecting the idea of one-dimensional female characters, looked at through the lens of a man. Eventually, this led to the inclusion of subjects that were left unexplored previously by the mainstream cinema, like female sexuality in 'Margarita With A Straw' or 'Lipstick Under My Burkha' and their decision making in movies like 'Pink' or 'Thappad'.

\section{Gender Inequality: As Portrayed in selected Female Oriented Bollywood Movies}

Over the years, there have been some movies highlighting women empowerment. But, this empowerment remains questionable from the ideological perspective. For instanceThe movie 'Chak De India' was a story of Indian female hockey team winning their first-ever World Cup Tournament not because they worked hard or had potential, rather since a male coach trained them. The first half of the movie shows them fighting like cats and were needed to be controlled and directed into a positive direction. Next, to get the sponsorship, they are asked to compete with the male hockey team, though the girls played brilliantly well, they still 
lose. But eventually, they do get the sponsorship to participate in the World Cup Tournament because of the generosity of the male hockey team. This scene tries to send out a message loud that no matter how well women are in their respective areas, they can never be better than men. And in the second half, even after all the coaching and teaching, the internal rivalry remains till the end, implying that the females can never unite.

The movie 'Pink' is a story of three middle-class normal working girls Minal, Falak and Andrea, who are out for a regular fun night to a rock concert. After the show, they accept a dinner invitation from a guy named Rajveer and two of his friends to a resort in Surajkund. Unfortunately, the night takes an ugly turn for them when Andrea finds herself being touched inappropriately by Dumpy (Raashul Tandon) whereas Rajveer forces himself onto Minal, despite her clearly saying 'No'. Thus in self-defence she picks up a bottle and smashes it on his head, leaving him bleeding. The girls immediately leave the resort, hoping the night will fade away. But their lives turn into a living hell when Rajveer using his powerful connections files an FIR against the girls. The film takes a dramatic turn when defence lawyer Deepak Sehgal (Amitabh Bachan) brings up the matter in court. The court-room sequence, inspired by Jonathan Kaplan's 'The Accused' (1988), where the accused Minal answers the questions on her virginity and drinking habits. 'Pink' lays bare the double standards of the society that we live in. It questions society's mindset where people think that girls with short hemlines and those who enjoy a drink with men are low on morals. Also, it echoes the message - that no matter if a woman is a sex-worker, wife or slave, if she says 'no' to being touched, then no man has the right to force himself on her. In spite of being a female-centric movie and one of its kind, Pink too highlighted the issue of Gender Inequality. It portrays all the three female leads as the damsels in distress, who asks for the help of another male, Deepak Sehgal (Amitabh Bachan) to prove themselves as innocents. The 
most famous dialogue, "No means No" was spoken not by any of the three female leads, but by the male lead, Amitabh Bachan.

'Ek Ladki Ko Dekha Toh Aisa Laga' is an unusual tale of finding love and acceptance. The movie starts with the traditional- when a boy meets a girl setup, where Sahil (Rajkumar Rao) finds himself fallen in love at first sight. A random, but pretty girl, Sweety (Sonam K. Ahuja), grabs his hand and pulls him into a chase and thus begins the story. Since Sahil is in love, he sets off on a path to track down the girl and profess his undying love to her. Later, he learns that she loves another girl, the major problem of the story. The girl's conservative Punjabi family too is pooled into the story, which includes, Beeji (Madhumalti Kapoor), Papaji, Balbir (Anil Kapoor) and Veerji (Abhishek Duhan) leading to a complete emotional family drama.

The movie uses a fair share of stereotypes to tell a modern and relevant love story. The fact that it brings a niche subject like homosexuality, to a mainstream movie, undoubtedly is one of its strengths. However, all that the movie offers is how Sahil (Rajkumar Rao) helps Sweety (Sonam K. Ahuja)- the damsel in distress, in convincing her father to accept her marrying to another girl. Although Sweety herself is in charge of her own life, still she looks up to the men (her father, her brother and later Sahil) to make decisions for her all her life.

The movie 'Veere Di Wedding' is a story of the journey of four friends from roughly from 18 years to 28 years as they talk about their boyfriend problems and then about husband problems. The movie begins with Kalindi (Kareena Kapoor Khan), who hesitatingly agrees to marry her three years old boyfriend, then changes her mind, and later changes it back again. Since the film is about women, it must feature Kalindi's three best friends in the plot. Each of her friends is representative of a different sort of marriage problem. One is married to a foreigner, and this is not acceptable to her father, leading to father-daughter estrangement (Shikha Talsania). One 
is on the verge of divorce (Swara Bhasker). And the third one has the biggest problem of them all- she is single in her late 20s (Sonam Kapoor Ahuja).

'Veere Di Wedding' claims to be a feministic movie, but the title itself does not do the justice to the film. In the opening scene, protagonist Kalindi tries to explain her mother-and the audience - the meaning of the word "veere"- "like bro". The story is not just about four women friends, but the women friends who are "cool bros" and that is the limit of the film's imaginative feministic storyline.

It was refreshing to see a mother dressing up her son in frocks. It was also refreshing to see a female protagonist masturbate on screen. It was even more refreshing to see a woman who is not waif-thin to be allowed a sexual life. However, the fact remains, it is a story of broculture; where super-affluent, upper-class women rather than celebrating and empowering womanhood, throughout the movie are either trying to play the role of men (veere) or trying to force men to play the role of women, which is completely evident in the song 'Tareefan' as well. The film tries to focus on gender equality, but all that it offers is bro-culture packaged as feminism and extending kindness or empathy only to the women within their network. The movie also sheds light on moral hypocrisy of all the aunties of the world who judge women who drink, smoke, love and abuse in public, for instance- the neighbourhood aunties who regularly pester Sakshi about her lifestyle and husband, or Kalindi's mothers-in-law to be (Rishabh's mother, and Sujata aunty).

Though the film does keep harping about its female-centricity, none of the female or male characters for that matter shows any explicit ideological commitment to the women's cause. Of course, the film has four women in the lead and no male superstar, also it has women producers. But it is hard to say whether the absence of a male lead has resulted in no hierarchy within the four women leads. 


\section{Conclusion}

Bollywood has changed significantly since its inception, making a name for it in and around the world. Indian films are being recognised throughout the world and are competing with western productions on the world stage, and winning several prestigious international awards. The success of Indian Cinema is spreading the Indian cultural traditions, dance and music to a global audience. Culture is one of the essential factors in modern society and Cinema, in particular, is acting as a mirror of society. It reflects the social struggles, ongoing trends, existing virtues, and the living patterns of people of a particular community. Thus it plays a vital role in depicting the Indian values to the world. The Indian films are famous around the globe since it connects with the diaspora. With globalisation, the Indian Cinema is becoming increasingly influenced by Western Cinema.

However, Bollywood still retains its Indian value and sticks to the traditional customs and life of the people in India. The roles played by women in Indian Cinema serve as a role model for other women with fewer opportunities to follow. With Bollywood being a big thriving industry, the female characters played in the movies allow the Indian women to relate themselves easily with these female characters. Women in real life are doing exceptionally well in their respective fields; thus it is the responsibility of the filmmakers to give them equally important and decisive roles compared to their male counterparts in movies; this will eventually help the movie-goers relate to the society in a better way. With movies like Dangal, Queen, Piku, Neerja, English Vinglish etc. doing exceptionally well, its time for more writers and producers come forward and be a part of this new feministic wave. 


\section{References}

Agarwal, R. (2014). Changing Role of Women in Indian Cinema. Silpakorn University Journal of Social Sciences, Humanities, and Arts, 14(2), 117-132.

Sharma, S., \& Narban, J. S. (2016). Indian Cinema and Women. International Journal of Advance Research and Innovative Ideas in Education, 2(1), 491-494.

Bala, A. (2014). Identity, Society and Gender Inequality of Women in North West India. Research Journal Of English Language And Literature, 2(1), 81-84.

Berger, J. (1973). Ways of seeing; a book made by John Berger. New York: Viking Press.

Falari, B. P. (2013). Literature To Films: A Study of Select Women Protagonists in Hindi Cinema, Goa.

Role \& Status of Women in India: Issues \& Challenges. (n.d.). Retrieved from https://www.poverties.org/blog/status-of-women-in-india.

Khatri, J. A. H. (2019, February 2). Light, camera, (stereotype) action: Bollywood's gender problem. Retrieved from https://enewsroom.in/woman-hindi-cinema-bollywoodgender/.

Pink Movie Review \{4.5/5\}: Critic Review of Pink by Times of India. (2016, September 14). Retrieved from https://timesofindia.indiatimes.com/entertainment/hindi/moviereviews/Pink/movie-review/54325066.cms.

Ek Ladki Ko Dekha Toh Aisa Laga Review $\{3.5 / 5\}$ : An entertaining and progressive look at love and acceptance. (2019, February 1). Retrieved from https://timesofindia.indiatimes.com/entertainment/hindi/movie-reviews/ek-ladki-kodekha-toh-aisa-laga/movie-review/67789472.cms.

Veere Di Wedding Has A Problem - Its Bro Culture ... (n.d.). Retrieved from https://feminisminindia.com/2018/06/04/veere-di-wedding-feminist-film-review/. 
Gender inequality - Oxford Reference. (2019, May 9). Retrieved from https://www.oxfordreference.com/view/10.1093/acref/9780198568506.001.0001/acre f-9780198568506-e-2834. 